\title{
An Ecological Survey of Hydrocarbon-oxidizing Micro-organisms
}

\author{
By J. G. JONES AND M. ANN EDINGTON \\ Department of Microbiology, University College of South Wales and \\ Monmouthshire, Cathays Park, Cardiff
}

(Accepted for publication I February 1968)

\begin{abstract}
SUMMARY
An ecological survey of the microflora of an upland moorland soil and the underlying shale was made over a 2-year period. Samples were taken at different depths of about 5,20 and $40 \mathrm{~cm}$. in the soil, and from the underlying shale band in a cave system nearby, and the average total counts of bacteria and fungi were $35 \times 10^{6}, 3 \times 10^{6}$ and $\mathrm{I} \times 10^{6}$ per g. dry wt respectively. Hydrocarbon-oxidizing organisms occurred in all the samples. The numbers and activity of these organisms were determined in a variety of ways and finally expressed as a function of the total population of each sample. A significantly higher proportion of the population of the $20 \mathrm{~cm}$. soil sample was able to utilize hydrocarbons as sole energy and carbon source, than of any of the other samples. When hydrocarbons were added there was a stimulation in respiration of all samples. Maximum stimulation of respiration occurred in the $20 \mathrm{~cm}$. soil sample. The $E_{h}$ of the $20 \mathrm{~cm}$. soil sample was lower than in any other sample, it also contained a higher level of lipid and hydrocarbons. It is suggested that the higher level of hydrocarbon oxidation in the $20 \mathrm{~cm}$. soil sample is due to the accumulation of hydrocarbons with a resulting adaptation of the microbial populations. More organisms were able to oxidize the longer chain $n$-aliphatic hydrocarbons than the short chain $n$-aliphatics, aromatic and alicyclic hydrocarbons. A list of the genera, including fungi, responsible for the oxidation of each hydrocarbon is given: the fungi play an important role in the hydrocarbon-oxidizing activity of each sample.
\end{abstract}

\section{INTRODUCTION}

The oxidation of hydrocarbons by micro-organisms has been well documented (Johnson, 1964; Van der Linden \& Thijsse, 1965). The study of such micro-organisms in natural systems has been confined to prospecting for oil fields (Brisbane \& Ladd, I965; Davis, Raymond \& Stanley, I959; Hitzman, I966), to facilitate the removal of crude oil from its source rock (Dostalek \& Spurny. 1958) and the removal of oil where it is a contaminant (Zobell \& Prokop, 1966). Geochemical analyses (Smith, 1954; Judson \& Murray, I956; Bergman, I963; Breger, I966; Stevenson, I966) have shown a widespread distribution of hydrocarbons in soils and recent sediments as well as in ancient sediments. By adapting techniques used in the past for petroleum prospecting we have made an ecological survey of the metabolism by micro-organisms of hydrocarbons which occur naturally in an upland moorland soil and underlying shale bands.

The upland moorland site (about I000 ft above sea level) is situated in the band of Carboniferous Limestone due north of the South Wales coal measures (Grid Reference 
$\mathrm{SN}$. 932II8). The soil is permanently waterlogged at the sampling points, the water table never falling more than $2 \mathrm{~cm}$. below the soil surface. Since the site is on fenced forestry commission land it is not grazed nor polluted by domestic animals; most of the organic matter entering the system is by turnover of the surface vegetation (Juncus articulatus and Molonia caerulea are co-dominant) and the washings from a nearby sphagnum pool. The underlying shale band was sampled at the Ogof-Ffynnon Ddu cave system, where the shale was undisturbed and not contaminated by surface soil washings as it is at its point of emergence at the upland moorland site.

\section{METHODS}

Sampling. The survey results are those of a sampling programme over two years from 1965 to 1967 . The upland moorland soil was sampled at three points, at depths of about 5,20 and $40 \mathrm{~cm}$. The upper samples were in $A_{0}$ horizon and the lower samples in the $A_{1}$ horizon. In all instances large samples (about $\mathrm{I} \mathrm{kg.)} \mathrm{were} \mathrm{taken} \mathrm{into} \mathrm{sterile}$ polythene bags, and about $15 \mathrm{~g}$. wet wt sample was removed aseptically from the centres of these samples in the laboratory for dilution. Similar aseptic techniques were used for sampling the shale in the cave system.

Microbiological methods. The dilution-plate count method was based on that described by Johnson, Curl, Bond \& Fribourg (1960). All dilutions were made into quarter-strength Ringer solution and counts made on a sample dry-wt basis. For each dilution plated, five or ten $0.1 \mathrm{ml}$. samples were spread with a sterile glass rod on to plates of medium. In all cases a second wipe plate was used. All plating was completed by $3 \mathrm{hr}$ after sampling.

Media. Bacteria and actinomycetes were plated on to modified soil extract agar (Bunt \& Rovira, 1955); fungi were estimated on peptone glucose agar with added rose bengal and aureomycin (Martin, 1950; Johnson, 1957). Obligate anaerobes were grown in a $\mathrm{H}_{2}$ atmosphere in an anaerobic jar on the Tryptone soy + salts agar of Iverson (I966); in some cases they were estimated as numbers of sulphite-reducing units in Iron Sulphite Agar (Oxoid). A basal salts medium was used for estimating hydrocarbon-oxidizing micro-organisms. This contained (g./l. distilled water) $\mathrm{K}_{2} \mathrm{HPO}_{4}$, $\mathrm{I} \cdot 0 ; \mathrm{MgSO}_{4} .7 \mathrm{H}_{2} \mathrm{O}, 0.2 ; \mathrm{CaCl}_{2} .2 \mathrm{H}_{2} \mathrm{O}, 0 . \mathrm{I} ; \mathrm{NaCl}, 0 . \mathrm{I} ; \mathrm{FeCl}_{3}, 0.0 \mathrm{I} ; \mathrm{NH}_{4} \mathrm{NO}_{3}, 0.5$; washed Oxoid Ionagar no. 2, 30. The Ionagar no. 2 was washed 24 times in glassdistilled water and twice in ethanol to remove organic contaminants. Selected hydrocarbons were used as sole carbon sources. Spread dilution plates were made, as described, on the basal mineral salts agar. Sterile filter paper was placed in the lid of the Petri dish and $0.5 \mathrm{ml}$. hydrocarbon soaked on to this filter paper and the plates then sealed with adhesive tape. In this way the given hydrocarbon was provided in the vapour phase. With all samples, but especially those with a low total bacterial count, this method was found to be more reproducible when the sample dilution was treated in one of the following ways. (a) Passed through a membrane filter $(0.45 \mu$ mesh), the filter rinsed with $10 \mathrm{ml}$. sterile quarter-strength Ringer solution, and placed on the basal mineral salts agar. (b) Centrifuged at $15,000 \mathrm{rev} . / \mathrm{min}$. (27,000 $\mathrm{g}$ ) for $20 \mathrm{~min}$., the deposit washed with sterile quarter-strength Ringer solution, centrifuged down and suspended in a known volume of Ringer solution before plating.

All experiments were done at $25^{\circ}$. Plates were counted at 4,7, I4 and 21 days according to the particular micro-organisms under study. All media were adjusted to the $\mathrm{pH}$ value of the samples taken. 
Characterization of the microflora. The initial characterization followed the method of Lochhead \& Chase (1943) to establish the nutritional groupings of the microflora of the samples. This method was then extended and an estimate was made of numbers of organisms (expressed as $\%$ of the total viable population of each sample) capable of growth with selected hydrocarbons as sole carbon + energy $(C+E)$ source. Growth was recorded after incubation for 7 days.

Following this initial survey estimates were made at each sampling period of the numbers of organisms capable of growth on a variety of single hydrocarbons as sole $\mathrm{C}+\mathrm{E}$ source. The organisms were grown, as described, on basal mineral salts agar with a hydrocarbon provided in the vapour phase. Sealed control plates without hydrocarbon were also inoculated; growth on these control plates would be due to residual organic matter in the Ionagar no. 2 or organic matter introduced with the inoculum; the number of colonies which developed was subtracted from the numbers obtained on the plates to which hydrocarbon had been added. When a particular species was found to have developed on the control plates then it was discounted on the experimental plates unless there was greater than tenfold stimulation in its growth, in which case it was considered to be of importance in the hydrocarbon metabolism of the sample. All instances of growth of species on hydrocarbons were checked by subculture on to a medium containing the test hydrocarbons as sole $\mathrm{C}+\mathrm{E}$ source.

Determination of microbial activity. All the methods involved measurement of stimulation in respiration of samples when various hydrocarbons were added as extra carbon source. For the initial survey soil and shale samples were incubated in $100 \mathrm{ml}$. Ehrlenmeyer flasks. Each flask contained a sample (about $0.5 \mathrm{~g}$. wet wt) of the soil or shale under study; basal mineral salts solution, $10 \mathrm{ml}$. (at $\mathrm{pH}$ value of sample); $20 \%$ $(\mathrm{w} / \mathrm{v}) \mathrm{KOH}$ solution $(0.5 \mathrm{ml}$.) in suspended Durham tube containing fluted filter paper; hydrocarbon $(0.5 \mathrm{ml}$.) absorbed on $5 \mathrm{~g}$. ignited sand. Control flasks contained no hydrocarbon and thermobarometer flasks no sample. A I ml. pipette was attached to each flask and at regular intervals over a period of several days a plug of Brodie manometer fluid was introduced into the pipette. The rate of $\mathrm{O}_{2}$ uptake was thus measured.

This experiment was repeated in conventional Warburg apparatus with the hydrocarbons which did not create vapour-pressure problems. Results in the Warburg respirometer were less reproducible probably because of the small size of sample introduced. Reports in the literature on the use of dried sieved soil (Stotzky \& Norman, I96I) led us to attempt this in the hope of increased reproducibility but such treatment altered considerably the respirometric activity of the samples. The results given here were obtained with soil and shale samples which were treated in a blendor for a few seconds and introduced into the Warburg flask by using a wide-mouthed pipette.

Enhancement of $\mathrm{CO}_{2}$ production by the samples by adding hydrocarbon was measured by adapting the methods of Stotzky \& Mortenson (1957) and Jackson (1958). Samples (100 g. wet wt) were mixed with $300 \mathrm{ml}$. basal mineral salts solution (adjusted to the $\mathrm{pH}$ value of the sample) and $\mathrm{IO} \mathrm{ml}$. hydrocarbon absorbed on ignited sand. Endogenous uptake flasks contained no added hydrocarbon and control flasks contained only basal mineral salts solution. $\mathrm{CO}_{2}$-free water-saturated air was drawn through the sample flasks; $\mathrm{CO}_{2}$ evolved was collected in $\mathrm{N}-\mathrm{NaOH}$ and determined titrimetrically. This method was, however, too cumbersome and too expensive of the natural materials to allow the replication necessary for statistical analysis. The 
experiment was therefore scaled down to $5 \mathrm{~g}$. wet wt samples incubated in closed vessels. After the incubation period, the $\mathrm{CO}_{2}$ produced was collected by boiling it off into $\mathrm{NaOH}$, followed by back titration. All respirometric results were corrected for sample dry weight and total viable microbial count of each sample, and finally expressed as percentage stimulation of respiration; the respiration rate of the endogenous or untreated sample was taken as $100 \%$.

In the population and respirometric analyses the data presented are the means of several tests. Each test involved 3,5 or Io replicates according to the analytical procedure used. Differences between mean readings were investigated by the $t$-test. All the results discussed differed significantly at $P=0.05$.

Chemical and physical analyses of samples. Throughout the period of study the soil or shale at the sampling sites were measured for $\mathrm{pH}$ value with a portable $\mathrm{pH}$ meter (Analytical Instruments Ltd.) with a soil probe attachment. $E_{h}$ values were measured with a platinum electrode with a calomel reference electrode and corrected to $\mathrm{pH} 7$. To obtain readings for the shale samples, they were mixed with distilled water (sample I g., distilled water $2.5 \mathrm{~g}$.). Total organic matter was determined by the Walkley-Black method as adapted by Jackson (1958). Total lipids were extracted for $24 \mathrm{hr}$ in a Soxhlet-type extractor with a chloroform + methanol $(2+\mathrm{I}, \mathrm{v} / \mathrm{v})$ mixture. The hydrocarbon content was determined by column chromatography of this extract on silica gel and alumina. The moisture contents of samples were determined by drying to constant weight at $105^{\circ}$.

\section{RESULTS}

\section{Numbers of micro-organisms}

Counts of micro-organisms in the soil samples over a period of I year showed typical poor soil annual cycle with a major peak in autumn and a minor one in spring. There was a decrease in numbers with depth of sample. This decrease applied to aerobic and anaerobic chemo-organotrophs (Fig. I). No such seasonal variation was found with the shale samples, due to the more stable cave environment (numbers varied from $3 \times 10^{5}$ to $1 \times 10^{6}$ organisms/g. dry wt shale. Anaerobic chemo-organotrophs were barely detectable in the shale samples. Fungi accounted for about $10 \%$ of the colony-forming particles of all samples.

\section{Physical and chemical analyses}

The shale was at about $\mathrm{pH} 7$, the soil samples were acid, increasingly with depth (Table I). Lowest $E_{h}$ values and maximum organic matter, lipid and hydrocarbon concentrations were found in the $20 \mathrm{~cm}$. deep soil sample. Normal paraffins were found in all samples.

\section{The activity of hydrocarbon-oxidizing organisms}

The initial population survey to determine the numbers of hydrocarbon-utilizing organisms in the samples showed the highest proportion of hydrocarbon oxidizers in the $20 \mathrm{~cm}$. soil sample. When the experiment was repeated with solid media with hydrocarbon provided in the vapour phase, the same general pattern was maintained (Table 2). 
Respirometric analyses to determine the microbiological activity of the soil samples show maximum stimulation by added hydrocarbon in the $20 \mathrm{~cm}$. sample. This is seen in the $\mathrm{O}_{2}$ uptake of the samples (Tables 3,4 ) as well as in the amount of $\mathrm{CO}_{2}$ evolved (Table 3). Although there are some inconsistencies (e.g. high activity in the $40 \mathrm{~cm}$. soil samples on addition of $n$-octane) it is clear that $20 \mathrm{~cm}$. soil samples show highest hydrocarbon oxidizing activity, in relation to its total population. High figures obtained witl shale samples are dealt with later.

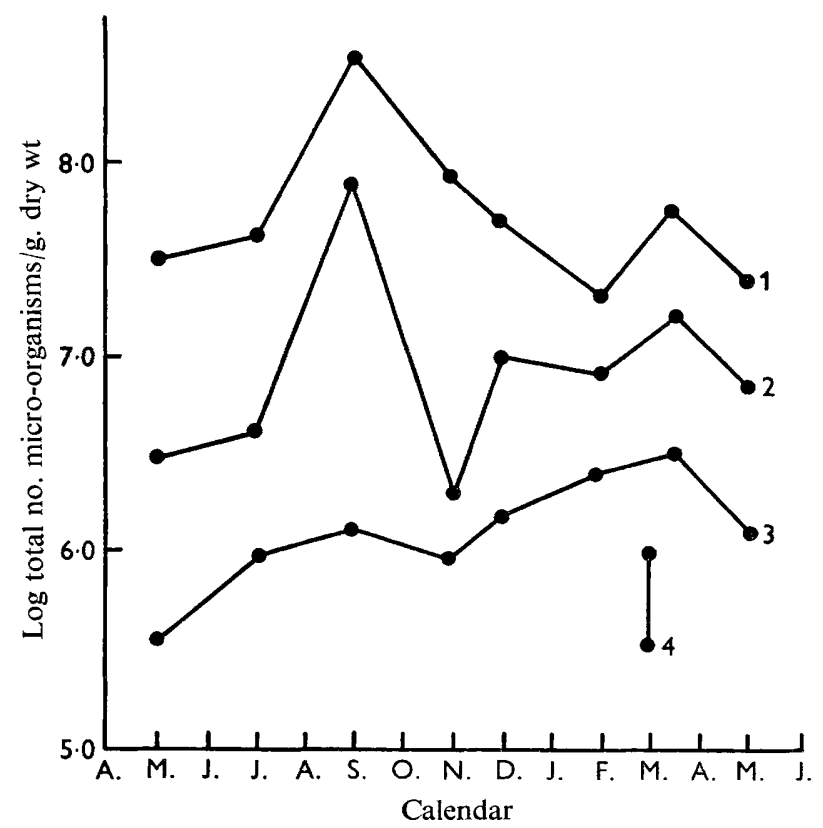

Fig. I. Seasonal variations in total counts of bacteria and fungi in soil and shale samples. Soil $4 \mathrm{~cm}$. sample, I; $20 \mathrm{~cm}$. sample, $2 ; 40 \mathrm{~cm}$. sample, 3; Shale sample, 4. Experimentat conditions: numbers of bacteria, actinomycetes and fungi were estimated by dilution counts on soil extract agar and peptone dextrose agar. Incubated at $25^{\circ}$. Shale samples showed no seasonal variation and the plots indicate the extremes of variation of numbers along the shale band.

Table I. Physical and chemical analysis of samples.

Results of a 2-year period of study

Soil

Sample depths (cm.)

$\mathrm{pH}$
$E_{h}(\mathrm{mV}$.
Moisture content
$\%$ dry weight
Organic matter
(mg./g.)
Lipid and hydro-
carbons (mg./g.)

\begin{tabular}{cccc}
5 & 20 & 40 & \multicolumn{1}{c}{ Shale } \\
$4 \cdot 8-6 \cdot 0$ & $3 \cdot 8-5 \cdot 0$ & $3 \cdot 2-3 \cdot 8$ & $7 \cdot 2-7 \cdot 5$ \\
+350 & +165 & +190 & +457 \\
$300-400$ & $550-900$ & $550-900$ & $5-10$ \\
150 & 800 & 400 & 15 \\
$1-9$ & $5-60$ & $2-20$ & $0 \cdot 1-1 \cdot 0$
\end{tabular}




\section{Table 2. Numbers of organisms capable of growth on selected hydrocarbons}

Sample dilutions were either washed by centrifugation or by membrane filtration. The washed samples or membrane filters were plated on to basal salts agar (set at pH sample). $0.5 \mathrm{ml}$. hydrocarbon was introduced into the lid of each sealed plate and thus the carbon source was provided in the vapour phase. Control plates contained no hydrocarbon. Incubated for 14 days at $25^{\circ}$. Percentage of total populations of samples capable of growth on hydrocarbons.

\begin{tabular}{|c|c|c|c|c|}
\hline \multirow[b]{2}{*}{ Hydrocarbon } & \multicolumn{3}{|c|}{$\begin{array}{c}\text { Soil } \\
\text { Sample depths (cm.) }\end{array}$} & \multirow[b]{2}{*}{ Shale } \\
\hline & 5 & 20 & 40 & \\
\hline$n$-Octane & $3(2-7)$ & $4(12-25)$ & I $(4-I 3)$ & $0.5(5)$ \\
\hline$n$-Decane & 4 & 8 & 2 & $1 \cdot 5$ \\
\hline n-Codecane & 13 & 17 & 20 & 3 \\
\hline$n$-Pentadecane & 7 & 10 & IO & 8 \\
\hline$n$-Hexadecane & $13($ i 5$)$ & $15(20-30)$ & $8(12-15)$ & $8(8-10)$ \\
\hline Benzene & $*-(0.5)$ & $2(5)$ & $\mathrm{I}(<0.5)$ & I (2) \\
\hline Toluene & $\ldots$ & - & - & 0.5 \\
\hline Cyclohexane & $0.5(0.5)$ & $3(6)$ & $0.5(0.5)$ & I (I) \\
\hline
\end{tabular}

* - Indicates that growth was not detectable by this method.

( ) Indicates figures obtained by adaptation of Lochhead \& Chase method ( 1943).

\section{Table 3. Stimulation of sample respiration by the addition of hydrocarbons}

$5 \mathrm{~g}$. (wet wt) sample was incubated with $0.5 \mathrm{ml}$. hydrocarbon (adsorbed on to ignited sand) and $\mathrm{ro} \mathrm{ml}$. basal salts solutions (set at $\mathrm{pH}$ of sample). A plug of Brodie manometer fluid was introduced into the $\mathrm{Iml}$. pipette attached to the reaction vessel. $\mathrm{O}_{2}$ uptake could thus be followed. Incubated at $25^{\circ}$. Percentage stimulation of $\mathrm{O}_{2}$ uptake.*

Soil

Sample depths (cm.)

\begin{tabular}{lrrrr}
\cline { 2 - 3 } \multicolumn{1}{c}{ Hydrocarbon } & 5 & 20 & 40 & Shale \\
$n$-Octane & 300 & 350 & 730 & 2480 \\
$n$-Decane & 510 & 1500 & 370 & 220 \\
$n$-Dodecane & 210 & 1750 & 590 & 115 \\
$n$-Hexadecane & 45 & 1170 & 1000 & 150 \\
Benzene & -160 & 270 & -280 & 940 \\
Toluene & 60 & -40 & -40 & 800 \\
Cyclohexane & 680 & 390 & 40 & 210
\end{tabular}

* Rate of respiration of untreated sample is taken as $100 \%$.

Table 4. Stimulation of sample respiration by the addition of hydrocarbons

These experiments were conducted in a conventional Warburg apparatus. Each flask contained, homogenized soil, $2.0 \mathrm{ml}$; $20 \%(\mathrm{w} / \mathrm{v}) \mathrm{KOH}, 0.2 \mathrm{ml}$; quarter-strength Ringer solutions, $0.75 \mathrm{ml}$; hydrocarbon $0.05 \mathrm{ml}$. Control flasks contained no hydrocarbon. Incubated at $25^{\circ}$. Percentage stimulation of $\mathrm{O}_{2}$ uptake.*

Soil

Sample depths (cm.)

$\begin{array}{lrrrr}\text { Hydrocarbon } & 5 & 20 & 40 & \text { Shale } \\ n \text {-Decane } & 60 & 100 & 20 & 200 \\ n \text {-Dodecane } & 160 & 400 & 30 & 1000\end{array}$

* Rate of respiration of untreated sample is taken as $100 \%$. 
In almost all samples a greater proportion of the population was capable of oxidizing longer chain $n$-aliphatic hydrocarbons than the shorter chain $n$-aliphatics, alicyclic or aromatic hydrocarbons. Comparatively low figures obtained with $n$-pentadecane and $n$-hexadecane are explained by their decreased availability due to lower solubility and volatility at the temperatures used.

We note that maximum hydrocarbon oxidation occurred where organic matter, lipid and hydrocarbon accumulation were at a maximum (Table I). The dominant microbial genera responsible for hydrocarbon oxidation in the samples studied were noted (Table 6). Several species of microfungi, although comparatively low in numbers, played an important part in the hydrocarbon-oxidizing activity of all the samples.

\title{
Table 5. Stimulation of sample respiration by addition of hydrocarbons
}

\begin{abstract}
Samples were incubated in closed flasks. Each flask contained, sample, $5 \mathrm{~g}$. (wet wt) basal salts solution, Io $\mathrm{ml}$. (set at $\mathrm{pH}$ of sample); hydrocarbon, $0.5 \mathrm{ml}$. (adsorbed on to ignited sand). The samples were incubated at $22^{\circ}$ for 3 days and then the gaseous contents were boiled off through $20 \mathrm{ml}$. $0 . \mathrm{I} \mathrm{N}-\mathrm{NaOH}$. $\mathrm{CO}_{2}$ production was determined titrimetrically. Percentage stimulation of $\mathrm{CO}_{2}$ production.*
\end{abstract}

\begin{tabular}{lcccr}
\multicolumn{3}{c}{$\begin{array}{c}\text { Soil } \\
\text { Symple depths (cm.) }\end{array}$} & Shale \\
$n$-Octane & 5 & 20 & 40 & 140 \\
$n$-Decane & 25 & 50 & 20 & 540 \\
$n$-Dodecane & 105 & 25 & 30 & 440 \\
$n$-Pentadecane & 210 & 1100 & 780 & 220 \\
$n$-Hexadecane & 360 & 650 & 320 & 160 \\
Benzene & 330 & 580 & 50 & -80 \\
Toluene & -30 & -75 & -30 & -140 \\
Cyclohexane & -5 & -100 & -30 & -60
\end{tabular}

* Rate of respiration of untreated sample is taken as $100 \%$.

\section{DISCUSSION}

The media used in this survey were chosen from many tested for maximum reproducibility of results. Adverse weather conditions (e.g. heavy rain) altered the physical, chemical and microbial characteristics of the soil considerably. The shale was free from climatic and seasonal variations.

The sample of lowest $E_{h}$ values (the $20 \mathrm{~cm}$. soil sample) was where most lipid and hydrocarbon material accumulated, and where the highest proportion of hydrocarbonmetabolizing micro-organisms were detected. The higher hydrocarbon content of this sample has probably caused adaptation of the microbial population resulting in the higher proportion of micro-organisms capable of hydrocarbon metabolism. Total numbers of hydrocarbon-oxidizing micro-organisms may be higher in the surface $(5 \mathrm{~cm}$.) soil sample, but other (e.g. physiochemical) factors may limit the development of the populations of the deeper soil samples and shale. Therefore, when comparing the nutritional characteristics of various populations, the numbers of a particular type of micro-organism should be expressed as a function of the whole population.

The presence of local soil microbial populations adapted to hydrocarbons forms the basis of microbial methods of oil prospecting (Brisbane \& Ladd, 1965) where gross differences occur between soils overlying oil and gas seeps and those not. The use of a 
Table 6. Dominant microbial genera responsible for hydrocarbon oxidation in the samples

Soil

Sample depths (cm.)

\begin{tabular}{|c|c|c|c|c|}
\hline Hydrocarbon & 5 & 20 & 40 & Shale \\
\hline n-Octane & $\begin{array}{l}\text { Saccharomyces } \\
\text { Unidentified Gram- } \\
\text { negative rod } \\
\text { Bacillus } \\
\text { Pseudomonas } \\
\text { Mycobacterium } \\
\text { Arthrobacter }\end{array}$ & $\begin{array}{l}\text { Nocardia } \\
\text { Unidentified Gram- } \\
\text { negative rod }\end{array}$ & $\begin{array}{l}\text { Pseudomonas } \\
\text { Nocardia }\end{array}$ & $\begin{array}{l}\text { Micrococcus } \\
\text { Arthrobacter 2 (spp.) }\end{array}$ \\
\hline n-Dodecane & $\begin{array}{l}\text { Penicillium (2 spp.) } \\
\text { Cladosporium (2 spp.) } \\
\text { Botrytis } \\
\text { Trichoderma } \\
\text { Spicaria } \\
\text { Saccharomyces (3 spp.) } \\
\text { Unidentified Gram- } \\
\text { negative rod } \\
\text { Pseudomonas }\end{array}$ & $\begin{array}{l}\text { Penicillium (3 spp.) } \\
\text { Saccharomyces (2 spp.) } \\
\text { Candida } \\
\text { Bacillus } \\
\text { Pseudomonas }\end{array}$ & $\begin{array}{l}\text { Pseudomonas } \\
\text { Nocardia (2 spp.) } \\
\text { Mycobacterium }\end{array}$ & $\begin{array}{l}\text { Penicillium } \\
\text { Corynebacterium } \\
\text { Micrococcus ( } 2 \text { spp.) }\end{array}$ \\
\hline$n$-Pentadecane & $\begin{array}{l}\text { Penicillium (2 spp.) } \\
\text { Sterile Basidiomycete } \\
\text { (unidentified) } \\
\text { Cephalosporium } \\
\text { Saccharomyces } \\
\text { Candida } \\
\text { Corynebacterium } \\
\text { Micrococcus } \\
\text { Unidentified Gram- } \\
\text { negative rods }\end{array}$ & $\begin{array}{l}\text { Penicillium (3 spp.) } \\
\text { Saccharomyces (2 spp.) } \\
\text { Pseudomonas } \\
\text { Nocardia }\end{array}$ & $\begin{array}{l}\text { Penicillium (2 spp.) } \\
\text { Aureobasidium }\end{array}$ & None isolated \\
\hline$n$-Hexadecane & $\begin{array}{l}\text { Penicillium } \\
\text { Trichoderma } \\
\text { Saccharomyces } \\
\text { Unidentified member of } \\
\text { the Form } \\
\text { Order Mycelia sterilia } \\
\text { Pseudomonas } \\
\text { Mycobacterium } \\
\text { Corynebacterium } \\
\text { Nocardia } \\
\text { Bacillus }\end{array}$ & $\begin{array}{l}\text { Penicillium (3 spp.) } \\
\text { Saccharomyces (2 spp.) } \\
\text { Candida } \\
\text { Mycobacterium } \\
\text { Bacillus }\end{array}$ & $\begin{array}{l}\text { Penicillium ( } 3 \text { spp.) } \\
\text { Aspergillus } \\
\text { Saccharomyces } \\
\text { Unidentified sterile } \\
\text { mycelium } \\
\text { Bacillus } \\
\text { Nocardia } \\
\text { Unidentified gram- } \\
\text { negative rods }\end{array}$ & $\begin{array}{l}\text { Penicillium } \\
\text { Aspergillus } \\
\text { Saccharomyces } \\
\text { Arthrobacter ( } 3 \mathrm{spp} .) \\
\text { Micrococcus (4 spp.) } \\
\text { Corynebacterium }\end{array}$ \\
\hline Benzene & None isolated & $\begin{array}{l}\text { Penicillium } \\
\text { Unidentified sterile } \\
\text { mycelium }\end{array}$ & None isolated & None isolated \\
\hline Cyclohexane & Penicillium & $\begin{array}{l}\text { Corynebacterium } \\
\text { Pseudomonas }\end{array}$ & $\begin{array}{l}\text { Unidentified sterile } \\
\text { mycelium }\end{array}$ & $\begin{array}{l}\text { Corynebacterium } \\
\text { (2 spp.) } \\
\text { Micrococcus } \\
\text { Nocardia } \\
\text { Sarcina }\end{array}$ \\
\hline
\end{tabular}

range of liquid instead of gaseous hydrocarbon substrates, accompanied by suitable statistical analyses allowed us to detect much smaller changes in the microflora of the samples.

All respirometric analyses were made using samples with microbial populations in the in vivo state. The conventional Warburg respirometer showed an immediate 
stimulation in $\mathrm{O}_{2}$ uptake on addition of hydrocarbons to the samples, indicating that a section of the sample microflora was already adapted to hydrocarbon metabolism. Respirometric analyses could only be used to compare samples of a similar nature (e.g. similar organic matter content). For example, the shale samples contain low numbers of hydrocarbon oxidizers but the respirometric results indicate a stimulation of as high as $1000 \%$ on addition of hydrocarbons. The shale contains much less easily oxidisable organic matter than the soil. Therefore stimulation in its respiration cannot be compared with that in soil because of the much lower rate of endogenous respiration in the shale. Very little is known about the effect of such varying soil factors on the growth of hydrocarbon-utilizing micro-organisms (Brisbane \& Ladd, I965), and differences in rates of endogenous respiration makes it difficult to interpret the stimulation of metabolism in a quantitative manner. Nevertheless, the results do indicate the presence or absence of significant numbers of hydrocarbon-oxidizing micro-organisms.

The use of solid media to demonstrate the presence of organisms capable of oxidizing gaseous hydrocarbons has been reported in the past (Davis et al. 1959). We have used this technique and provided the liquid hydrocarbon in the vapour phase, but we found that pretreatment of the samples by membrane filtration or washing made the technique somewhat laborious.

Any one species of hydrocarbon-oxidizing micro-organism can usually metabolize longer chain $n$-aliphatic hydrocarbons more easily than short chain $n$-aliphatic, alicyclic or aromatic hydrocarbons (Johnson, 1964). This survey has shown that this is also a property of naturally occurring mixed populations. In all samples a higher proportion of the population was capable of oxidizing $n$-dodecane, $n$-pentadecane, and $n$-hexadecane and $n$-octane, benzene, toluene or cyclohexane. The microbial genera responsible for hydrocarbon metabolism have been repeatedly and consistently isolated from the samples.

This survey is part of a wider scheme of study concerned with the role of microorganisms in the biogenesis and turnover of naturally occurring hydrocarbons, and was carried out during the tenure of an S.R.C. Studentship (J.G.J.). We thank the Forestry Commission for access to the upland moorland site.

\section{REFERENCES}

Bergman, W. (1963). Geochemistry of lipids. In Organic Geochemistry, p. 503. Oxford: Pergamon Press.

Breger, I. A. (I966). Geochemistry of lipids. J. Am. Oil Chem. Soc. 43, 197.

Brisbane, P. G. \& LAdD, J. N. (1965). The role of micro-organisms in petroleum exploration. A. Rev. Microbiol. 19, 351 .

Bunt, J. S. \& RoviRA, A. D. (1955). Microbiological studies of some subantarctic soils. J. Soil Sci. 6, II 9 .

Davis, J. B., Raymond, R. L. \& Stanley, J. P. (1959). Areal contrasts in abundance of hydrocarbon oxidising microbes in soils. Appl. Microbiol. 7, 156.

Dostalek, M. \& Spurny, M. (1958). Bacterial release of oil. Folia biol., Praha 4, I66.

Hitzman, D. O. (I966). Prospecting for petroleum deposits. U.S. Patent 3,28I,333.

IVERSON, W. P. (1966). Growth of Desulphovibrio on the surface of agar media. Appl. Microbiol. I4 (4), 529.

JACKSON, M. L. (I958). Oxidizable matter by chromic acid with $\mathrm{H}_{2} \mathrm{SO}_{4}$ heat of dilution. In Soil Chemical Analysis, p. 219. London: Constable and Co. Ltd. 
JoHnson, L. F. (1957). Effects of antibiotics on the numbers of bacteria and fungi isolated from soil by dilution plate method. Phytopathology 47,630 .

Johnson, L. F., Curl, E. A., Bond, J. H. \& Fribourg, H. A. (1960). In Methods for Studying Soil Microflora-Plant Disease Relationships. Minneapolis: Burgess Publishing Co.

Johnson, N. J. (1964). Utilization of hydrocarbons by micro-organisms. Chemy Ind. 36, I 532.

Judson, S. \& Murray, R. C. (1956). Modern hydrocarbons in two Wisconsin lakes. Bull. Am. Ass. Petrol. Geol. 40, 747.

LOCHHEAD, A. G. \& CHASE, F. E. (1943). Qualitative studies of soil micro-organisms. V. Nutritional requirements of the predominant bacterial flora. Soil Sci. 55, 185 .

MARTIN, J. P. (1950). Use of acid, rose bengal and streptomycin in the plate method for estimating soil fungi. Soil Sci. $69,215$.

SMITH, P. V. (1954). Studies on the origin of petroleum: occurrences of hydrocarbons in recent sediments. Bull. Am. Ass. Petrol. Geol. 38, 383.

Stevenson, F. J. (I966). Lipids in soil. J. Am. Oil Chem. Soc. 43, 203.

Stotzky, G. \& MoRTENson, J. L. (1957). Effect of crop residues and nitrogen additions on decomposition of an Ohio muck soil. Soil Sci. $83,165$.

Stotzky, G. \& Norman, A. G. (I96I). Factors limiting microbial activities in soil. Arch. Mikrobiol. 40, 34I.

Van der Linden, A. C. \& Thissse, G. J.E. (1965). The mechanisms of microbial oxidations of petroleum hydrocarbons. Adv. Enzymol. 27, 469 .

ZoBell, C. E. \& Prokop, J. F. (1966). Microbial oxidation of mineral oils in the Barataria Bay bottom deposits. Z. allg. Mikrobiol. 6, 143. 